\title{
Schooling and conflict in Darfur: A snapshot of basic education services for displaced children
}

Cynthia B. Lloyd

Population Council

Safaa El-Kogali

Population Council

Jenny Perlman Robinson

Johanna Rankin

Population Council

Ali Rashed

Population Council

Follow this and additional works at: https://knowledgecommons.popcouncil.org/departments_sbsr-pgy

Part of the Demography, Population, and Ecology Commons, Gender Equity in Education Commons, and the International Public Health Commons

How does access to this work benefit you? Let us know!

\section{Recommended Citation}

Lloyd, Cynthia B., Safaa El-Kogali, Jenny Perlman Robinson, Johanna Rankin, and Ali Rashed. 2010.

"Schooling and conflict in Darfur: A snapshot of basic education services for displaced children." New York: Population Council and Women's Refugee Commission.

This Report is brought to you for free and open access by the Population Council. 


\section{SCHOOLING AND CONFLICT IN DARFUR:}

\section{A SNAPSHOT OF BASIC EDUCATION SERVICES FOR DISPLACED CHILDREN}
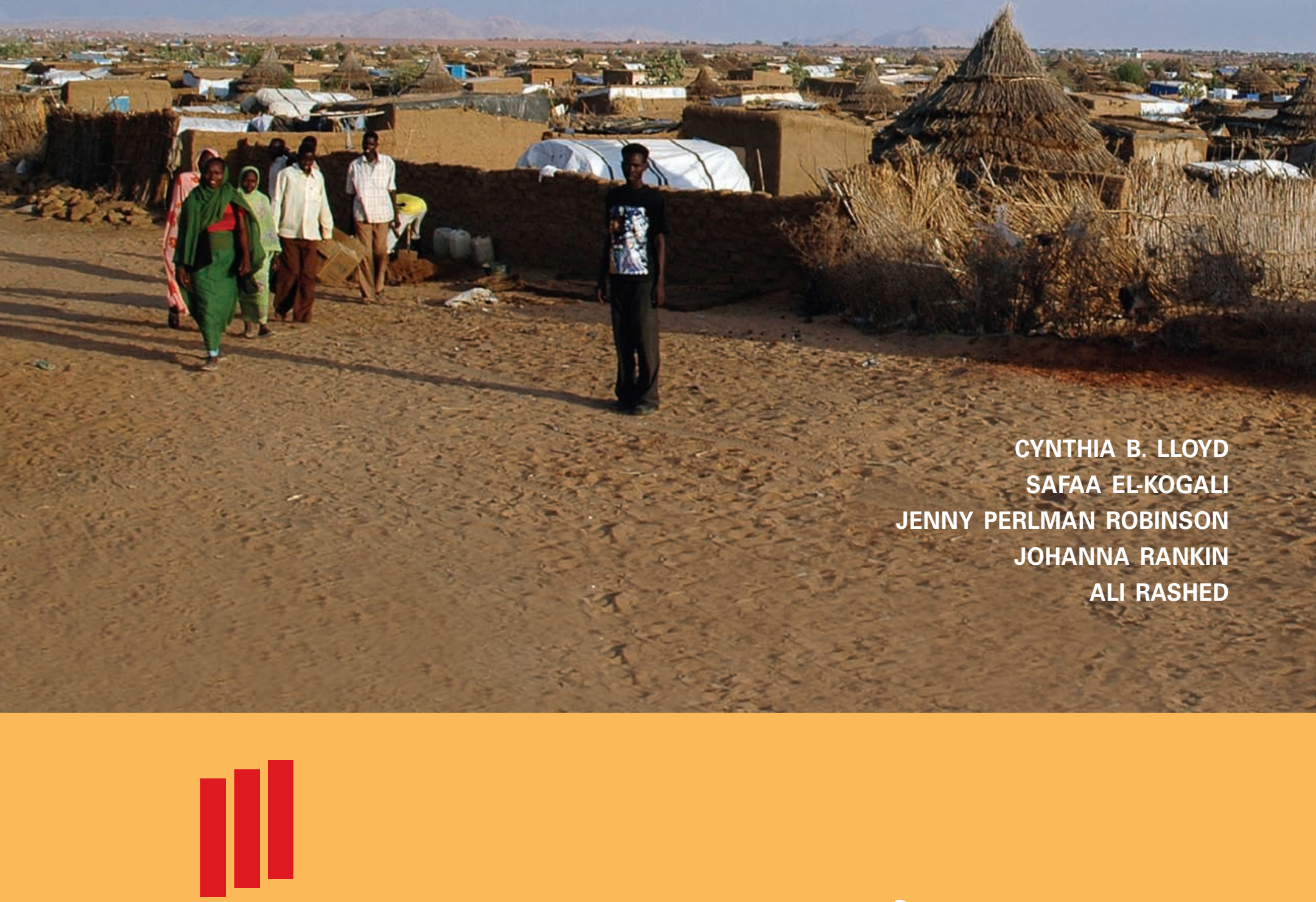

WOMEN'S 


\section{SCHOOLING AND CONFLICT IN DARFUR:}

A SNAPSHOT OF BASIC EDUCATION SERVICES FOR DISPLACED CHILDREN

CYNTHIA B. LLOYD

SAFAA EL-KOGALI JENNY PERLMAN ROBINSON JOHANNA RANKIN ALI RASHED

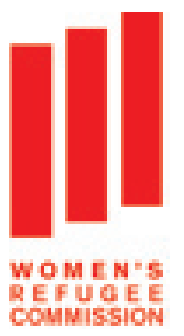

(2) Population Council 
(c) 2010 The Population Council, Inc.

\section{(P Population Council}

The Population Council conducts research worldwide to improve policies, programs, and products in three areas: HIV and AIDS; poverty, gender, and youth; and reproductive health.

Population Council

One Dag Hammarskjold Plaza

New York, NY 10017 USA

www.popcouncil.org

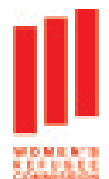

The Women's Refugee Commission advocates vigorously for laws, policies and programs to improve the lives and protect the rights of refugee and internally displaced women, children and young people, including those seeking asylum-bringing about lasting, measurable change.

Women's Refugee Commission

122 East 42nd Street

New York, NY 10168 USA

WwW.womensrefugeecommission.org

Any part of this publication may be photocopied without permission from the authors or publishers, provided that publication credit is given and that copies are distributed free. Any commercial reproduction requires prior written permission from the Population Council.

Cover photo: Ragui Assaad 


\section{Contents}

Preface $\quad$ V

Acknowledgments vii

Executive Summary 1

Background on the conflict in Darfur $\quad 5$

\begin{tabular}{ll} 
Study design & 5 \\
\hline
\end{tabular}

$\begin{array}{ll}\text { Data collection } & 7\end{array}$

\begin{tabular}{ll} 
Diversity among sample communities & 7 \\
\hline
\end{tabular}

$\begin{array}{ll}\text { Provision of educational services } & 8\end{array}$

\begin{tabular}{lr} 
Primary school access & 9 \\
\hline
\end{tabular}

\begin{tabular}{ll} 
Primary school resources & 11 \\
\hline
\end{tabular}

\begin{tabular}{ll} 
Primary school teachers & 12 \\
\hline
\end{tabular}

\begin{tabular}{ll} 
Conclusions & 15 \\
\hline
\end{tabular}

\begin{tabular}{ll} 
Notes & 15 \\
\hline
\end{tabular}

Table 1. Sample categories by sampling characteristics 6

Table 2. Communities sampled relative to communities listed 6

Table 3. Sample population of displaced persons relative to total displaced population 6

Table 4. Educational resources by community $\quad 8$

Table 5. Descriptive data on primary schools $\quad 9$

Table 6. Distribution of schools by number of grades offered and date of establishment 10

$\begin{array}{ll}\text { Table 7. Primary school access by type and sex } & 10\end{array}$

$\begin{array}{ll}\text { Table 8. Primary school resources } & 11\end{array}$

Table 9. Teacher characteristics 13

Table 10. Primary school teachers available relative to educational needs $\quad 14$

Annex 1. Map of affected populations in Darfur, including affected populations in the study sample 16

$\begin{array}{ll}\text { Annex 2. Challenges of undertaking research in Darfur } & 17\end{array}$

$\begin{array}{lr}\text { Annex 3. Key features of IDP communities in the sample } & 18\end{array}$ 


\section{Preface}

$\mathrm{E}$ ducation has been long neglected in emergency relief efforts. In 2007, Save the Children estimated that more than 39 million children and youth who are affected by armed conflict do not have access to education. In mid-2007, the Women's Refugee Commission (formerly called the Women's Commission for Refugee Women and Children) approached the Population Council about conducting research on the protective role of education in conflict. The result was a collaboration between the two organizations on a research project in Darfur, Sudan. The Darfur region has been significantly affected by displacement from ongoing conflict. Given the large size of the affected population, the level of international involvement, and the documented violations against children and youth, Darfur serves as a compelling case study of the extent of educational coverage for primary-school-age children in this setting as well as certain basic elements of educational quality. The ultimate goal of the project was to improve the well-being of displaced children and youth through increasing the provision of quality and safe education. This report is the outcome of the research project.

Cynthia B. Lloyd, the principal author of the report, was involved with the project from concept to completion, taking a lead role in fundraising, project design, data analysis, and report writing. She was a senior associate with the Population Council, based in New York, when the project was launched and continues as a consulting senior associate. She has extensive expertise on education and adolescent issues in developing countries.

Safaa El-Kogali was a member of the international advisory committee for the project since its inception in early 2008 . She became the principal investigator on the project when she joined the Population Council at the end of 2008 as regional director for the Middle East and
North Africa based in Cairo. Since then, she has served as a liaison for the project's collaborators in Sudan and provided overall guidance for the completion of the data analysis. She has contributed to the report, especially in terms of the key messages and recommendations. She has extensive experience on education in conflict and post-conflict settings, where most recently she managed the World Bank's education program in Iraq.

Jenny Perlman Robinson is senior program officer for children and youth at the Women's Refugee Commission and has been involved in the project from concept to completion, providing strategic advice during the project's development and timely critique during the report's preparation. She has also been the chief spokesperson for the project in the humanitarian community and served as the liaison for the project with its advisory committee. She has extensive experience on issues of children and youth in refugee and internally displaced settings.

Johanna Rankin is a research analyst based in the New York office of the Population Council. She joined the Council in 2007 and participated in the project's first team meeting in Cairo, convened for the purpose of developing a sampling plan for the project and designing the questionnaires. She became the key New York liaison for the field team, backstopping them from New York on issues related to implementation of the field work, including sampling, logistics, questionnaire wording, confidentiality, and informed consent. She assisted Ali Rashed in Cairo with data management and analysis. She also developed the project protocols for the Institutional Review Board (IRB), serving as a liaison with the IRB throughout the project.

Ali Rashed, a data analyst based in Cairo, conducted all data tabulations in the report. This involved initially working with the raw 
data collected from the field and creating data files from which the data could more easily be analyzed using STATA.

We hope that the findings in this report will demonstrate the importance of building the evidence base for policies and programs targeted to conflict-affected populations. We also hope that it contributes to the knowledge base on education in emergency settings, providing an example for further work in other conflict areas.

Cynthia B. Lloyd

SAFAa El-Kogali

Jenny Perlman Robinson

JOHANNA RANKIN

Ali Rashed 


\section{Acknowledgments}

$\mathrm{F}$ irst and foremost, we acknowledge the excellent contributions from our field team, who, despite challenges and difficult conditions, managed to visit all but one of the communities that had been selected for the study and undertook the research faithfully and carefully. The team was led by Dr. Manzoul Assal, Professor of Anthropology at the University of Khartoum, who was ably assisted by two supervisors-Zahir Abdel Karim Musa and Abubakr Adam Suliman. Other members of the field team were Haibat Ahmed Alsanwsi and Soad Yoousif Ibrahim. Our field logisticians were Alnour Ishag Adam and Nour El deen Mohamed Belo. The questionnaires were translated by Nauman Alameen and Rayeed Yousif.

Dr. Ragui Assaad, the former regional director for the Population Council in Cairo, was instrumental in raising the funding for the project and in developing the sampling design. El Daw Suliman, the previous principal investigator on the project, managed all aspects of the project until his departure from the Population Council in December 2008. Sara Musa, the manager of the Population Council office in Khartoum, took responsibility for liaison with the Government of Sudan and UN officers in Khartoum and provided essential logistical support.

Data on locations of internally displaced persons (IDP) settlements and their population size were provided by the United Nations Office for the Coordination of Humanitarian Affairs (OCHA), and were used to select a sample of communities/settlements for the community mapping and school census phase. OCHA also provided detailed and up-to-date maps (at no cost) of the locations of the IDP settlements, which were used in measuring distances of settlements from major cities and town. OCHA added the Population Council-Khartoum to its mailing list for regular security updates on Darfur, and we received regular security updates from OCHA through emails.

We thank the Humanitarian Aid Commission for granting permission for the study and providing support to the team in the field. The Ministry of Education provided useful information and support, and the World Food Programme provided assistance with flights to remote internally displaced communities. UN Humanitarian Air Service provided transport for team members during fieldwork, and Save the Children USA supported and provided accommodation to the team.

The project was guided from the beginning by an international advisory committee whose members were: Allison Anderson (Inter-Agency Network for Education in Emergencies), Dana Burde (New York University), Eluned RobertsSchweitzer (formerly Save the Children and currently World Bank), Michael Gibbons (independent consultant), Marc Sommers (Tufts University), Jackie Kirk (deceased, formerly International Rescue Committee), Pilar Aguilar (UNICEF), and Jeannie Annan (formerly Yale University and currently International Rescue Committee).

Funding for the project was provided by grants from the John D. and Catherine T. MacArthur Foundation and the UK Department for International Development (DFID).

Cynthia B. Lloyd

SafaA El-Kogali

Jenny Perlman Robinson JOHANNA RANKIN

Ali Rashed 


\section{Executive Summary}

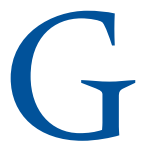
lobally, there has been increased attention to children's education in conflict-affected countries, with a particular focus on the provision of basic schooling. Nonetheless, representative data from these settings remain scarce. In many settings where displacement has persisted over a long period, it is widely assumed that all children have access to primary schooling and that available schools provide instruction in all grades necessary for primary school completion. However, given the lack of current data, the actual coverage and quality of schools in settings suffering from protracted displacement are unknown, making it impossible for service providers and donors to plan, prioritize, and respond to educational needs.

To address this lack of information, the Population Council, in collaboration with the Women's Refugee Commission, conducted a survey of basic educational services and facilities in a scientifically selected sample of 17 of the 68 internally displaced persons (IDP) communities in North and West Darfur during the second half of 2008.* The survey was designed to provide a more accurate picture of the state of formal and non-formal education for displaced children of primary school age (6-14-year-olds). This report aims to provide donors, policymakers, and practitioners with on-the-ground information to help them plan and implement effective, targeted educational programs. It identifies gaps in school coverage and access for girls and boys, and highlights issues that affect the quality of education, such as facilities, class size, and teacher training and availability. The report calls into question some of the assumptions often made about the coverage of basic schooling in settings with long-term conflict and displacement, highlights recommendations to improve children's access to quality education, and notes lessons learned about conducting scientifically grounded data collection among communities containing internally displaced persons in unstable settings such as Darfur.

\section{Key findings}

Half of the primary schools provided instruction in all eight grades. A total of 81 primary schools were found to be serving the displaced population in the 17 communities visited. However, only 45 of these schools ( 56 percent) provided instruction in all eight grades. While roughly three-quarters of single-sex schools provided instruction in all eight grades, no more than a third of co-ed schools (the majority of schools established since the beginning of the conflict in 2003) provided complete instruction in all required grades.

\section{Girls and boys had equal access to primary} school. At least one school was available for boys and one school for girls in every IDP community. ${ }^{\dagger}$ Roughly half the schools were co-ed and half were single-sex, with an equal number of allboys and all-girls schools. Equity of access is determined by the number of full-gradeequivalent primary schools ${ }^{\ddagger}$ in each community

* For reasons of security, the survey did not cover IDP communities in South Darfur.

${ }^{\dagger}$ Access was determined by whether or not there was a school within the community or nearby that was attended by IDP children. For displaced boys, access would require the presence of a co-ed or an all-boys school. For displaced girls, access would require a co-ed or an all-girls school. Access was based not on distance but on actual use.

₹To allow for the fact that children have less than full access to primary school when an available school provides less than eight grades of instruction, a school with fewer than eight grades is counted as a partial school with an adjustment calculated on the basis of the number of grades actually taught. Thus, a school with four grades would be counted as half a school. 
available to boys and to girls. While ten communities had equal access, girls were favored in the number of full-grade-equivalent schools available to them in three communities and boys were favored in four communities.

Despite equal access, girls lag in enrollment in some communities. Displaced girls comprised 44 percent of IDP enrollment in primary schools in the 17 communities visited. While girls accounted for up to 50 percent of enrollment in most communities, in five communities girls' enrollment ranged from 33 to 41 percent.

Access to water and sanitation was lacking at many schools. Less than half of schools had school feeding programs. Only 60 percent of primary schools reported having water inside the schoolyard. More schools had toilet facilities (typically pit latrines), with 80 percent of girls-only schools, 70 percent of boys-only schools, and 90 percent of co-ed schools having toilets. Schools providing instruction in all eight grades were better provisioned with water but less well provisioned with toilets despite the greater age range of children served.

Shortages of teachers were common. To sustain a class size of 50 , one teacher is needed for every 250 displaced persons. While population estimates vary, two communities had an estimated shortage of more than 100 teachers. Only four communities were adequately supplied with teachers. In general, shortages ranged from as few as ten to as many as 70 teachers. While 55 percent of all primary school teachers were female, the distribution of female teachers varied greatly from community to community. In two communities an average of 10 percent of teachers were female; at the other extreme in two communities roughly 70 percent of teachers were female.

Half of all teachers lacked qualifications. Large variations were found in teachers' experience and qualifications across communities. Mean years of teaching experience per community varied from four to 11 years (with a mean of nine years), and the percentage of teachers with teaching certificates varied from 9 percent to 87 percent (with a mean of 47 percent). While overall no more than 8 percent of teachers were reported to be volunteers, in one community almost all teachers were volunteers.*

Student-to-teacher ratios exceeding 50:1 were characteristic of many schools in West Darfur. On the other hand, student-to-teacher ratios below 50 were characteristic of all communities visited in North Darfur. In both states, student-to-teacher ratios were much greater (68) in co-ed schools than in single-sex schools (49-50).

Non-formal educational alternatives were rare. Non-formal educational programs typically focused on youth and/or adults and seldom targeted primary-school-age children who were not attending formal school. None of the 17 communities visited had accelerated learning programs that would have allowed children who had failed to start formal schooling to enter the formal system.

Scientifically grounded research is possible in conflict-affected settings. Conflict-affected settings pose unusual challenges to researchers not just because of problems related to safety, transportation, and communication but also because of conflicting agendas by rival groups that can affect access, numbers reported, and services offered. Necessary permission and logistical arrangements typically require the services of a logistician to coordinate transportation and communication. Provisions must be made for the safety of researchers (including evacuation plans in case of emergency) and the security of data (including rapid transmission out of the country), dissemination of which can pose a threat to groups that seek to promote alternative views of reality. If these precautions are taken, research visits can be based on random selection rather than on convenience. An account of the challenges of undertaking this research study in Darfur is provided in Annex 2.

* This may be explained by a recent change made by the Government of Sudan to grant volunteer teachers permanent status. 


\section{Recommendations}

While policymakers, donors, and practitioners are increasingly focused on providing educational services for displaced children, these programs need to be better targeted and adapted to the diverse circumstances in displaced communities. To ensure that all children have access to quality basic education, the Government of Sudan and its international partners need to take into account the specific contexts and conditions when designing policies and planning and implementing basic educational programs.

While not exhaustive, the following recommendations include key actions that the Government of Sudan and the humanitarian community should take, in accordance with the Inter-Agency Network for Education in Emergencies (INEE) Minimum Standards* and in response to the findings in this report:

Expand all primary schools serving displaced children to include instruction in all eight grades. While primary schools exist in every community visited, many need to be expanded to offer children a complete primary education in all eight grades.

* The INEE Minimum Standards are the internationally agreed-upon framework for building and/or rebuilding quality educational systems in crisis and post-crisis settings. Particularly relevant here are Access and Learning Environment Standards. http://www.ineesite.org/index.php/post/inee_ minimum_standards_overview/
Ensure that communities have a sufficient number of appropriately qualified teachers to provide universal basic education. These teachers should be recruited on the basis of criteria that reflect competence, diversity, and gender equity.

Provide appropriate support services to promote school attendance and retention. This should include school feeding programs to meet nutritional needs and provide access to water and sanitation facilities, taking into account the specific needs of girls and students with disabilities.

Establish non-formal educational and vocational training programs for children who have missed out on primary school and are no longer age-appropriate or who have dropped out before completing primary school. These programs are intended to provide alternatives to the formal education system.

Support further community-based research to assess the role of education in the lives of displaced children, including the household factors constraining children's participation in school. Ensure that the data collected are disaggregated according to sex, age, and particular needs and that the information is documented, analyzed, and disseminated. 


\section{Background on the conflict in Darfur}

$\mathrm{T}$ he current conflict in Darfur began in February 2003, when two loosely allied rebel groups, the Justice and Equality Movement (JEM) and the Sudan Liberation Movement/Army (SLM/SLA), took up arms against the Government of Sudan (GoS), demanding a stake in power and wealth sharing. The GoS responded by mounting an aerial bombardment and supporting ground attacks by a militia group, the Janjaweed (loosely translated as "devils on horseback"). ${ }^{1}$ In May 2006, the GoS and a faction of the SLA under the rebel leader Minni Minnawi agreed to implement a ceasefire and to sign the Darfur Peace Agreement (DPA); however, another faction of the SLA, led by Abdel Wahid Mohammed Ahmed El-Nur (SLAAW), and the rebel group JEM refused to sign. Ultimately, the DPA failed, its scope too limited and its signatories too few. Opposition to the DPA exacerbated tribal divisions and sparked new waves of violence. As of 2008, there were an estimated 30 rebel groups in Darfur, and the distinction between them and government forces has blurred. ${ }^{2}$ Nonetheless, the practice by the government, its allied militias, and rebels of systemically targeting civilians has continued. ${ }^{3}$

In July 2008, the International Criminal Court (ICC) filed ten charges of war crimes against the president of Sudan, Omar al-Bashir, and in March 2009 the ICC handed down the indictment of the president. In response, the GoS expelled 13 international humanitarian aid organizations. ${ }^{4}$ Prior to the indictment, Darfur rebels had been engaged in peace talks with the GoS. However, days after the ICC filings, the rebels disengaged from the talks, arguing that there was no need to continue after the ICC indictment.

The impact of the conflict has been immense and widespread. Some analysts estimate that more than 300,000 civilians have been killed. ${ }^{5}$ As of January 1, 2009, an estimated 2.7 million persons were internally displaced in Darfur, with 316,000 of these either newly or re-displaced during 2008. ${ }^{6}$ Moreover, the expulsion of aid organizations left a void in life-sustaining services within Darfur. Given the escalating violence and insecurity, it seems unlikely that people will return home in the near future. Humanitarian insecurity and lack of access have created desperate situations in some IDP camps, particularly in inaccessible rural communities. ${ }^{7}$ More than six years into the conflict, the security situation in Darfur continues to deteriorate.

\section{Study design}

The conflict in the Darfur region of Sudan had internally displaced roughly 1.3 million people in North and West Darfur by October 2008, at the time this study was conducted. ${ }^{8}$ With 26 percent of the Sudanese population in the age range $5-14,{ }^{9}$ an estimated 338,000 of the internally displaced persons (IDPs) in these two states were of primary school age and therefore in need of education. From June to December 2008, the Population Council, in collaboration with the Women's Refugee Commission, conducted a baseline survey of educational facilities serving internally displaced children living in the states of North Darfur and West Darfur. (For reasons of security, the survey did not cover IDP communities in South Darfur.) These facilities included both formal primary schools and non-formal educational programs serving primary-school-age children.

The purpose of the study was to assess the reach of basic schooling to the displaced populations in diverse settings and to document aspects of school quality. The researchers were not able to conduct a full assessment of the Inter-Agency Network for Education in Emergencies Minimum Standards for Education in Emergencies, Chronic Crises and Early Reconstruction (INEE Minimum Standards), as that would have required a longer stay and much more extensive training. Nonetheless, some of the data collected can provide information on a few of INEE's recommended indicators related to protection and well-being as well as facilities; in particular, sanitation, drinking water, and nutrition. ${ }^{10}$ 
The study was designed to depict the full range of living conditions and educational services available to the displaced population of Darfur, living either in formal and non-formal settlements or in towns other than the state capital. ${ }^{11}$ To characterize the diversity among communities, settlements were organized into six categories using indicators of potential resource access. These included distance from the state capital and from the nearest town and estimated size of population. ${ }^{12}$ Communities were defined as near if they were within 42 miles of a town or the state capital and were defined as small if their estimated population was less than 9,800. Table 1 shows the distribution of these six categories by size and location.

The goal was to select 12 communities in North Darfur and 12 in West Darfur, two randomly from each of the six categories indicated above, with backup communities (also selected randomly) in case a particular community proved inaccessible at the time of the field visits. The communities in each state listed by the United Nations Office for the Coordination of Humanitarian Affairs (OCHA) were sorted into one of the six categories. A random number generator was used to select two communities, with backup communities selected as well. In West Darfur, ten communities were included in the sample out of 48 eligible for selection. ${ }^{13}$ In North Darfur, seven communities were included in the sample out of the 20 eligible for selection (see Table 2). ${ }^{14}$

Based on OCHA population estimates for October 2008, the ten selected communities in West Darfur covered about 25 percent of the displaced population estimated to be living in the state, while our sample of seven communities in North Darfur covered about 30 percent of the state's displaced population (Table 3).

TABLE 1 Sample categories by sampling characteristics

\begin{tabular}{lcc}
\hline & $\begin{array}{c}\text { Small } \\
\text { population }\end{array}$ & $\begin{array}{c}\text { Large } \\
\text { population }\end{array}$ \\
\hline Near state capital & 1 & 2 \\
Far from state capital & & \\
$\quad$ Nearby town & 3 & 4 \\
No nearby town & 5 & 6 \\
\hline
\end{tabular}

${ }^{a}$ Less than 9,800.
TABLE 2 Communities sampled relative to communities listed

\begin{tabular}{lcc}
\hline $\begin{array}{l}\text { Community } \\
\text { characteristics }\end{array}$ & $\begin{array}{c}\text { West } \\
\text { Darfur }\end{array}$ & $\begin{array}{c}\text { North } \\
\text { Darfur }\end{array}$ \\
\hline Near state capital (within 42 miles) & $4 / 24$ & $3 / 9$ \\
Near town (within 42 miles) & $2 / 7$ & $3 / 6$ \\
Far from town or capital (beyond 42 miles) & $4 / 17$ & $1 / 5$ \\
Total & $10 / 48$ & $7 / 20$ \\
\hline
\end{tabular}

The map in Annex 1 indicates all the IDP communities from which our sample was drawn and highlights the communities included in our sample. The IDP communities selected in North Darfur are Abbasi from category 1, Zamzam and Al Salam from category 2, Fata Borno from category 3, Birka Seira and Kassab from category 5, and El Seiraf from category 6. The IDP communities selected in West Darfur are Dorti and Kondobe from category 1, Riyadh and Mornei from category 2, Habila and Forbaranga from category 4, Arara and Kongo Haraza from category 5, and Deleij and Nertiti from category 6. These 17 IDP communities represent all of the size and distance categories originally laid out in the sampling plan.

The local study director hired and trained four local interviewers. All of the interviewers were natives of Darfur ${ }^{15}$ and current or former university students. Each community was visited by a team of two interviewers, one male and one female. Much time was dedicated before the beginning of our field visits in June 2008 to consultations with government officials in Khartoum as well as in El Fashir (capital city of North Darfur) and El Geneina (capital city of West Darfur) in order to explain the study and seek their collaboration and permission. Some of the challenges of data collection in these settings are described in Annex 2.

TABLE 3 Sample population of displaced persons relative to total displaced population

\begin{tabular}{|c|c|c|c|}
\hline & $\begin{array}{l}\text { West } \\
\text { Darfur }\end{array}$ & $\begin{array}{l}\text { North } \\
\text { Darfur }\end{array}$ & Total \\
\hline Total population & 766,363 & 508,499 & $1,274,862$ \\
\hline $\begin{array}{l}\text { Population of sample } \\
\text { communities }\end{array}$ & 188,195 & 154,861 & 343,056 \\
\hline $\begin{array}{l}\text { Percent of IDP } \\
\text { population sampled }\end{array}$ & 25 & 30 & 27 \\
\hline
\end{tabular}

SOURCE: OCHA, Darfur HNP Profile No. 33, 2008. 


\section{Data collection}

Data collection at the community level was organized in two steps. The first step involved a visit to the local omda or sheikh (traditional leader) to characterize each community in terms of its population, geography, history of settlement, and educational service environment. Our interviewers were asked to draw a map of the community with all notable services identified and to consult knowledgeable community members in addition to the omda or sheikh, if necessary, to complete the map.

The community questionnaire included questions on the following:

- all formal primary schools attended by IDPs residing in the community, by name and type

- all non-formal educational programs available to the residents, by name, type, and target population

- all centers where any type of service is provided to the displaced population, by name and type

- all offices, including non-governmental organizations (NGOs), United Nations (UN), and government, by name and type

- all organizations, groups, and resources that serve the IDP community, by name and type

- availability of psychosocial support for children

- presence of activities for children during school vacations

- recent informational/education campaigns

- history and demography of settlement

- estimated population size

The second step was a visit to each of the formal primary schools identified. ${ }^{16}$ Detailed information about each school was collected from a teacher or head teacher. The data collected included information about the following:

- school type (co-ed versus single-sex)

- date established

- grades taught

- sources of funding

- school administration

- school facilities, including water, toilet, and furnishings
- school term dates and time of daily sessions

- school services (nutrition, first aid, psychosocial support, etc.)

- involvement by international nongovernmental organizations (INGOs) or UN agencies

- teacher roster by grade taught, sex, educational background, experience, and residence

- student enrollment by grade, sex, and IDP status

Qualitative data were also collected from a sample of key informants in each community in North Darfur on issues primarily related to educational conditions. An analysis of these data will be presented in a forthcoming report.

\section{Diversity among sample communities}

The IDP communities sampled differed from one another according to many characteristics, including year of initial displacement of the resident population, the ethnic diversity of the settlement, the overall population size, the number of new arrivals, and the extent to which the displaced population had access to educational opportunities available to the host population. Communities also differed in terms of the presence of NGOs, access to external resources as a result of proximity to a town or capital city, the number of formal and non-formal schools in relation to the school-age population, and other facilities, in particular health facilities.

In most of the communities visited in North Darfur, the displaced population lived in contained settlements and in most cases did not have access to the schools attended by the host community, even when the settlement was near a town. However, there were exceptions where IDPs and host children attended the same schools. The living circumstances of the IDPs in West Darfur were more diverse, and, in many of these communities, the displaced lived on the edge of a town and some resided among the host community without clear boundaries.

Annex 3 provides information about the history of each settlement, the number and identity of ethnic groups who live in the settlement, the rough size of the IDP population, and whether outside organizations were supporting educational efforts in the 
community. ${ }^{17}$ It is notable that among the ten selected communities in West Darfur, all were settled within a period of 15 months, with the most recent community settled in January 2004. By contrast, the seven target communities in North Darfur show much more variation with respect to settlement date, ranging from March 2003 to April 2007. There is also a large range of settlement sizes in West Darfur, while in North Darfur the settlements visited were either small (less than 10,000) or very large (more than 30,000). Most settlements included IDPs from more than one ethnic group, and some have four or more ethnic groups residing together. In Annex 3 and in all subsequent tables, the settlements are ordered within each state according to the date of settlement, with the community settled earliest listed first.

The presence of outside organizations in the community that provided support to the education sector (to either the formal system or the non-formal system, including preschool) was fairly common at the time of our survey, with ten of the 17 communities reporting some involvement, typically by INGOs (all ten), but occasionally by UN agencies (four communities) or bilateral agencies (one community). However, no outside agencies were reported to be active in Deleij, Mornei, Arara, and Kongo Haraza in West Darfur or in Abbasi, El Seiraf, and Birka Seira in North Darfur. This absence was particularly notable in Deleij and Mornei, which had large populations of IDPs.

\section{Provision of educational services}

All 17 communities visited had at least one formal primary school available to both girls and boys (even those far from the capital or town) and some had many more. Table 4 provides an overview of the range of educational services available by community in each state. In West Darfur, four of the ten communities had formal secondary schools in the host communities that were accessible to IDPs, while in North Darfur none of the seven camps had a secondary school nearby that would have

TABLE 4 Educational resources by community

\begin{tabular}{|c|c|c|c|c|c|c|c|c|c|}
\hline \multirow[b]{3}{*}{$\begin{array}{l}\text { State/ } \\
\text { community }\end{array}$} & \multirow{2}{*}{\multicolumn{3}{|c|}{ Number of schools by type }} & \multicolumn{2}{|c|}{$\begin{array}{c}\text { Number of nonformal } \\
\text { programs by type }\end{array}$} & \multirow{2}{*}{\multicolumn{4}{|c|}{$\begin{array}{c}\text { Presence of } \\
\text { specific educational activities }\end{array}$}} \\
\hline & & & & \multirow{2}{*}{$\begin{array}{c}\text { Nonformal } \\
\text { literacy } \\
\text { programs } \\
\text { (primary } \\
\text { children } \\
\text { named as } \\
\text { target group) }\end{array}$} & \multirow[b]{2}{*}{$\begin{array}{l}\text { Nonformal } \\
\text { livelihood/ } \\
\text { vocational } \\
\text { programs }\end{array}$} & & & & \\
\hline & $\begin{array}{l}\text { Formal } \\
\text { primary } \\
\text { schools }\end{array}$ & $\begin{array}{c}\text { Formal } \\
\text { secondary } \\
\text { schools } \\
\text { accessible } \\
\text { to IDPs }\end{array}$ & $\begin{array}{l}\text { Koranic } \\
\text { schools }\end{array}$ & & & $\begin{array}{l}\text { Information } \\
\text { campaigns } \\
\text { on health } \\
\text { and safety }\end{array}$ & $\begin{array}{c}\text { Information } \\
\text { campaigns } \\
\text { on } \\
\text { education }\end{array}$ & $\begin{array}{c}\text { Activities } \\
\text { for } \\
\text { children } \\
\text { during } \\
\text { vacation }\end{array}$ & $\begin{array}{l}\text { Psycho- } \\
\text { social } \\
\text { support } \\
\text { for } \\
\text { children }\end{array}$ \\
\hline \multicolumn{10}{|l|}{ West Darfur } \\
\hline Kondobe & 1 & & 13 & 1 & & * & * & & \\
\hline Kongo Haraza & 3 & & & & & * & & & \\
\hline Habila & 5 & 1 & & 5 & 6 & & * & & * \\
\hline Mornei & 10 & 2 & & & 1 & * & * & * & \\
\hline Riyadh & 3 & & & $2(1)$ & & * & & & \\
\hline Forbaranga & 12 & 3 & 1 & & 1 & * & & & \\
\hline Arara & 4 & & 1 & & & & & & \\
\hline Deleij & 3 & 1 & 3 & & & * & & & \\
\hline Dorti & 1 & & & $1(1)$ & & * & & & \\
\hline Nertiti & 2 & & & $2(1)$ & & * & & & \\
\hline \multicolumn{10}{|l|}{ North Darfur } \\
\hline Kassab & 12 & & & 4 & 2 & * & & $*$ & \\
\hline Birka Seira & 1 & & 6 & 4 & 1 & & & & \\
\hline Fata Borno & 2 & & & 3 & & * & & * & * \\
\hline Zamzam & 9 & & 2 & & & & & & \\
\hline Abbasi & 2 & & & 1 & & * & & & \\
\hline Al Salam & 9 & & & 1 & & * & & & $*$ \\
\hline El Seiraf & 2 & & 3 & & & & & & \\
\hline
\end{tabular}

NOTE: * means the particular feature is provided in the community. 
been easy to access. Secondary schools are typically located in the nearby towns or host communities. For IDPs to attend, they must travel to the town or relocate to a nearby area. Koranic schools were present in seven of the 17 communities. Koranic schools were particularly numerous in Kondobe in West Darfur, with 13 schools, and in Birka Seira in North Darfur, with six such schools.

While five communities in each state reported that some form of non-formal literacy training was available as an alternative to formal schooling, in only a few cases were primary-school-age children named as a target group. Typically the target group for literacy training included all ages, sometimes mixed and sometimes separate for each sex, with the lower age limit for eligibility ranging from 14 to 18 . Thus, primary-school-age internally displaced children in these communities had few educational options beyond formal primary school. Five of the communities reported one or more livelihood or vocational programs, typically for those over age 18 but occasionally serving younger adolescents. From these data, we conclude that most communities were underserved by livelihood/vocational programs for older children and young adults.

The presence of educational activities also varied significantly. While almost all communities had some sort of information campaign focusing on health or safety, only three communities in West Darfur had conducted information campaigns to encourage school enrollment. With few exceptions, no provisions were made for school children during school vacations; only three camps reported activities, including sports in one and group tutoring in another. In the few cases where psychosocial support was available to children, a teacher or school director was named as the provider of such support, frequently during class time.

\section{Primary school access}

A total of 81 primary schools were visited during the field research-44 in West Darfur and 37 in North Darfur. This covered all primary schools attended by internally displaced children in the sample communities (Table 5). Twenty-one of the primary schools visited in West Darfur and nine visited in North Darfur had been established
TABLE 5 Descriptive data on primary schools

\begin{tabular}{|c|c|c|c|c|}
\hline & \multicolumn{2}{|c|}{$\begin{array}{l}\text { Number of } \\
\text { schools }\end{array}$} & \multicolumn{2}{|c|}{$\begin{array}{c}\text { Percent } \\
\text { distribution }\end{array}$} \\
\hline & $\begin{array}{l}\text { West } \\
\text { Darfur }\end{array}$ & $\begin{array}{l}\text { North } \\
\text { Darfur }\end{array}$ & $\begin{array}{c}\text { West } \\
\text { Darfur }\end{array}$ & $\begin{array}{l}\text { North } \\
\text { Darfur }\end{array}$ \\
\hline Total & 44 & 37 & 100 & 100 \\
\hline \multicolumn{5}{|l|}{ School type } \\
\hline Co-ed & 28 & 13 & 64 & 35 \\
\hline Boys only & 7 & 13 & 16 & 35 \\
\hline Girls only & 9 & 11 & 20 & 30 \\
\hline \multicolumn{5}{|c|}{ Establishment date } \\
\hline Pre-2003 & 21 & 9 & 48 & 24 \\
\hline $2003+$ & 23 & 28 & 52 & 76 \\
\hline \multicolumn{5}{|c|}{ No. of grades taught } \\
\hline$<4$ & 7 & 1 & 16 & 3 \\
\hline $4-7$ & 17 & 11 & 39 & 30 \\
\hline 8 & 20 & 25 & 45 & 68 \\
\hline \multicolumn{5}{|c|}{ IDP enrollment } \\
\hline $100 \%$ & 39 & 30 & 89 & 81 \\
\hline$<100 \%$ & 5 & 7 & 11 & 19 \\
\hline
\end{tabular}

before the conflict began in 2003. Slightly more than half of the schools visited in West Darfur and nearly three-quarters of the schools visited in North Darfur, however, had been established since the beginning of the conflict to address the needs of displaced children. The overwhelming majority of all the schools (69 of 81) were attended exclusively by internally displaced children. Access can be measured not just in terms of the number of schools available but also in terms of the number of grades taught and the length of the school day.

Roughly half of primary schools visited provided instruction in all eight grades. Formal primary schools serving the IDP population are run by the Government of Sudan and follow the same design and curriculum as in the rest of the country. A primary school in Sudan consists of eight grades of instruction. Less than half the schools in our sample communities in West Darfur provided all eight grades, compared with almost 70 percent of the schools in North Darfur. Schools established since the conflict began were much less likely to provide all eight grades of instruction (see Table 6). There is enormous variation in primary educational coverage from settlement to settlement, with all schools in four communities in North Darfur teaching all eight grades while three communities had no schools with all eight grades. Eight of the 81 schools provided fewer than four grades while 28 offered four to seven grades. Single-sex schools were much more likely 
TABLE 6 Distribution of schools by number of grades offered and date of establishment

\begin{tabular}{lccccccc}
\hline \multirow{2}{*}{$\begin{array}{l}\text { Grades } \\
\text { offered }\end{array}$} & \multicolumn{3}{c}{ West Darfur } & & \multicolumn{3}{c}{ North Darfur } \\
\cline { 2 - 4 } & Pre-2003 & $\mathbf{2 0 0 3 +}$ & Total & & Pre-2003 & 2003+ & Total \\
\hline $4-7$ & 0 & 7 & 7 & & 0 & 1 & 1 \\
8 & 5 & 12 & 17 & & 0 & 11 & 11 \\
Total & 16 & 4 & 20 & & 9 & 16 & 25 \\
\hline
\end{tabular}

to provide all eight grades of instruction (70-85 percent) than co-ed schools (34 percent), which were more recently established.

\section{Displaced boys and girls had equal access to} primary school in the majority of communities visited. While the majority of schools visited in West Darfur served both sexes, in North Darfur singlesex education was common, with only a little less than a third of schools enrolling both boys and girls. Given that primary schools were not always co-ed, it is important to determine whether displaced girls had equal access to schools relative to displaced boys. We developed a school access indicator to measure the number of full-gradeequivalent schools in each community. This indicator adjusts each school for its completeness of instruction. Table 7 indicates that primary school access was equal for boys and girls in the majority of communities-five in West Darfur and five in North Darfur. In three communities in West Darfur, girls had slightly greater access than boys, and in four communities boys had slightly greater access.

Despite roughly equal access to primary schools, girls still lag behind in enrollment. Overall, 44 percent of IDP enrollment in primary schools surveyed was female (last column of Table 7). Eight of the communities came close to 50 percent, while, in two others, no more than a third of enrollment was made up of girls. In one

TABLE 7 Primary school access by type and sex

\begin{tabular}{|c|c|c|c|c|c|c|c|}
\hline \multirow[b]{2}{*}{$\begin{array}{l}\text { State/ } \\
\text { community }\end{array}$} & \multicolumn{3}{|c|}{$\begin{array}{l}\text { No. of full-grade- } \\
\text { equivalent schools }\end{array}$} & \multicolumn{3}{|c|}{ Equity of access } & \multirow{2}{*}{$\begin{array}{c}\text { Girls' }^{\prime} \\
\text { enrollmen } \\
\text { as } \% \text { of } \\
\text { total IDP } \\
\text { enrollmen }\end{array}$} \\
\hline & $\begin{array}{c}\text { All } \\
\text { schools }\end{array}$ & $\begin{array}{l}\text { Schools } \\
\text { accessible } \\
\text { to boys }\end{array}$ & $\begin{array}{l}\text { Schools } \\
\text { accessible } \\
\text { to girls }\end{array}$ & $\begin{array}{l}\text { Equal } \\
\text { access }\end{array}$ & $\begin{array}{c}\text { Boys } \\
\text { favored }\end{array}$ & $\begin{array}{c}\text { Girls } \\
\text { favored }\end{array}$ & \\
\hline \multicolumn{8}{|l|}{ West Darfur } \\
\hline Kondobe & 0.75 & 0.75 & 0.75 & * & & & 40 \\
\hline Kongo Haraza & 2.00 & 1.25 & 2.00 & & & * & 46 \\
\hline Habila & 4.13 & 3.13 & 3.13 & * & & & 45 \\
\hline Mornei & 8.75 & 7.75 & 8.75 & & & * & 41 \\
\hline Riyadh & 2.13 & 2.13 & 2.13 & * & & & 49 \\
\hline Forbaranga & 9.25 & 6.75 & 6.25 & & * & & 33 \\
\hline Arara & 2.75 & 1.75 & 1.75 & * & & & 47 \\
\hline Deleij & 2.50 & 1.63 & 1.50 & & * & & 48 \\
\hline Dorti & 0.63 & 0.63 & 0.63 & * & & & 48 \\
\hline Nertiti & 1.88 & 0.88 & 1.00 & & & * & 50 \\
\hline \multicolumn{8}{|l|}{ North Darfur } \\
\hline Kassab & 9.00 & 5.00 & 5.00 & * & & & 43 \\
\hline Birka Seira & 2.00 & 1.00 & 1.00 & * & & & 34 \\
\hline Fata Borno & 1.00 & 1.00 & 1.00 & * & & & 51 \\
\hline Zamzam & 8.00 & 4.75 & 4.00 & & * & & 49 \\
\hline Abbasi & 2.00 & 1.00 & 1.00 & * & & & 50 \\
\hline Al Salam & 9.25 & 8.25 & 6.63 & & * & & 47 \\
\hline El Seiraf & 1.63 & 1.63 & 1.63 & * & & & 48 \\
\hline
\end{tabular}

NOTE: * means the particular type of access is found in the community. 
of these communities-Birka Seira—girls had equal access to primary schools but nonetheless enrollment for girls was much lower than for boys. Even more surprising is the case of Mornei, where girls had access to more full-gradeequivalent schools than boys but only made up 41 percent of total enrollment. Clearly, in some settings the availability of a school is not sufficient to equalize enrollment on the part of girls. This could be due to constraints on the demand side, whereby families do not allow their daughters to go to school for any number of reasons (poverty and opportunity cost, security, cultural norms, etc.). Reduced female enrollment could also be due to constraints on the supply side, whereby school quality was poor in terms of availability of essential facilities, such as water and toilets. It could also be due to a lack of teachers in general or female teachers in particular. Research has shown that the quality of education, in terms of basic facilities and availability of female teachers, is a significant factor affecting female enrollment.

\section{Primary school resources}

Table 8 presents data on resources available for primary schools separated by community and school type (co-ed, girls only, and boys only). These resources include some of the elements listed under the INEE's recommended indicators related to protection and well-being as well as facilities; in particular, sanitation, drinking water, and nutrition. Access to water and to toilet facilities within the school is an important measure of the physical quality of the school for children and its potential for protection. When girls and boys attend schools with such facilities, they are less likely to have to travel back and forth to their home to use these facilities.

Food is provided in slightly less than half the primary schools surveyed. Typically either all the schools in a community or settlement provided food to students or none did so. Boys-only schools were slightly more likely to have a

TABLE 8 Primary school resources

\begin{tabular}{|c|c|c|c|c|c|c|c|c|}
\hline \multirow{3}{*}{$\begin{array}{l}\text { State/ } \\
\text { community/ } \\
\text { school type }\end{array}$} & \multicolumn{4}{|c|}{ Percent } & & & & \multirow{3}{*}{$\begin{array}{c}\text { Mean hours } \\
\text { in session } \\
\text { per week }\end{array}$} \\
\hline & \multirow{2}{*}{$\begin{array}{c}\text { Complete } \\
\text { schools } \\
\text { as \% of } \\
\text { total } \\
\text { schools }\end{array}$} & \multirow[b]{2}{*}{$\begin{array}{l}\text { Feeding } \\
\text { program }\end{array}$} & \multirow[b]{2}{*}{ Water } & \multirow[b]{2}{*}{ Toilet } & \multicolumn{3}{|c|}{$\begin{array}{l}\text { Percent of schools receiving } \\
\text { NGO funding for }\end{array}$} & \\
\hline & & & & & Building & Salaries & $\begin{array}{l}\text { Annual } \\
\text { costs }\end{array}$ & \\
\hline \multicolumn{9}{|l|}{ West Darfur } \\
\hline Kondobe & 0 & 0 & 0 & 100 & 100 & 0 & 0 & 35 \\
\hline Kongo Haraza & 33 & 0 & 0 & 33 & 33 & 0 & 0 & 40 \\
\hline Habila & 40 & 100 & 100 & 100 & 100 & 60 & 0 & 38 \\
\hline Mornei & 60 & 0 & 100 & 100 & 90 & 50 & 50 & 35 \\
\hline Riyadh & 33 & 100 & 100 & 100 & 100 & 100 & 0 & 37 \\
\hline Forbaranga & 50 & 92 & 58 & 100 & 92 & 25 & 17 & 30 \\
\hline Arara & 50 & 0 & 25 & 100 & 50 & 0 & 0 & 37 \\
\hline Deleij & 33 & 0 & 33 & 67 & 67 & 33 & 0 & 38 \\
\hline Dorti & 0 & 100 & 100 & 100 & 100 & 0 & 0 & 35 \\
\hline Nertiti & 50 & 0 & 50 & 100 & 100 & 0 & 50 & 37 \\
\hline \multicolumn{9}{|l|}{ North Darfur } \\
\hline Kassab & 100 & 100 & 100 & 44 & 56 & 0 & 89 & 40 \\
\hline Birka Seira & 100 & 100 & 50 & 100 & 0 & 0 & 0 & 37 \\
\hline Fata Borno & 100 & 100 & 100 & 100 & 100 & 0 & 100 & 38 \\
\hline Zamzam & 67 & 33 & 44 & 56 & 100 & 0 & 22 & 37 \\
\hline Abbasi & 100 & 100 & 0 & 100 & 100 & 0 & 0 & 38 \\
\hline Al Salam & 45 & 9 & 45 & 91 & 100 & 0 & 36 & 35 \\
\hline El Seiraf & 0 & 0 & 0 & 67 & 100 & 0 & 0 & 32 \\
\hline Total & 56 & 47 & 60 & 83 & 84 & 19 & 28 & 36 \\
\hline Co-ed & 34 & 37 & 59 & 90 & 90 & 29 & 27 & 35 \\
\hline Girls only & 70 & 50 & 70 & 80 & 85 & 5 & 25 & 38 \\
\hline Boys only & 85 & 65 & 55 & 70 & 70 & 10 & 35 & 38 \\
\hline
\end{tabular}


feeding program (65 percent) than girls-only schools ( 50 percent) or co-ed schools ( 37 percent). Schools that exclusively served the IDP population were less likely to provide food than schools with a mixed student population of IDPs and non-IDPs (39 percent versus 92 percent). On the other hand, primary schools providing all eight grades of instruction were more likely to have feeding programs than those with fewer grades (data not shown).

Only 60 percent of the primary schools sampled reported having water inside the schoolyard. In four of the target communities, none of the primary schools had access to water. Access to water is slightly more prevalent in girls-only schools (70 percent) than in boys-only schools ( 55 percent) or co-ed schools (59 percent) and also slightly more prevalent in schools providing instruction in all eight primary grades (data not shown).

More schools had toilet facilities (typically pit latrine) than had water. Overall, 83 percent of the primary schools had toilet facilities: 80 percent of girls-only schools, 70 percent of boys-only schools, and 90 percent of co-ed schools. Schools providing instruction in all eight grades were slightly less likely to have toilet facilities, which is surprising given their need to serve a wider age range of students (data not shown).

Primary school construction was heavily funded by outside agencies. The most typical way that INGOs and UN agencies (e.g., UNICEF) contributed to formal schooling was through funding school construction. Overall, 85 percent of schools surveyed had some external support for school construction. In ten of the 17 communities, 100 percent of schools benefited from such contributions. In all but one of the remaining communities, INGOs were involved in building some of the schools. Almost all schools built since 2003 received external funding for building construction.

Other types of contributions made directly to the schools from external agencies were much less common. This is probably because teachers' salaries are the responsibility of the Government of Sudan, and donors are less likely to contribute to these large, recurrent costs. Nonetheless, 19 percent of the primary schools in the sample reported some INGO or UN contribution to salaries, and 28 percent reported some contribution by external agencies to the funding of annual school costs.

The school day was relatively long. All primary schools met five days a week. The number of hours schools were in session varied from six to eight. ${ }^{18}$ Typically the number of school hours was around 37-39 per week, but schools in two communities-one in West Darfur and one in North Darfur-met on average only 30-32 hours per week. Single-shift schools were the norm; only one of the 81 schools in the sample had two shifts.

\section{Primary school teachers}

The availability of female teachers varied widely from community to community. Table 9 presents data on teacher characteristics. The most striking statistic is the percentage of teachers who were female, based on data on 1,400 teachers from the 81 primary schools visited. ${ }^{19}$ While a majority of teachers were female ( 55 percent), the percentage varied from a high of 70 percent to a low of 11 percent. Evidence shows that girls fare better with female teachers. ${ }^{20}$ Given this fact, it is ironic that a higher percentage of teachers in all-boys schools were female than in all-girls schools. These data suggest that the teaching and school environment varies considerably from community to community. There is no evidence from the data to suggest in this context, however, that the percentage of girls in the classroom was correlated with the percentage of teachers who are female or that the percentage of teachers who are female is correlated with the number of grades of instruction provided in the school.

There were large variations in teachers' experience and qualifications. The percentage of teachers who resided in the community or IDP settlement is important because there is evidence that teacher absenteeism is greatest in communities where teachers are not local residents. In four communities all teachers resided in the settlement, whereas in other communities few, if any, did so. Overall, about a third of teachers lived in the settlements, with fewer teachers in co-ed schools than in single-sex schools living in the settlements.

Variations across settlements are equally striking in the percentage of teachers with 
TABLE 9 Teacher characteristics

\begin{tabular}{|c|c|c|c|c|c|}
\hline \multirow{2}{*}{$\begin{array}{l}\text { State/ } \\
\text { community/ } \\
\text { school type }\end{array}$} & \multicolumn{4}{|c|}{ Percent } & \multirow{2}{*}{$\begin{array}{c}\text { Mean } \\
\text { years of } \\
\text { teaching } \\
\text { experience }\end{array}$} \\
\hline & Female & $\begin{array}{l}\text { Resident } \\
\text { in camp }\end{array}$ & Volunteer & $\begin{array}{l}\text { Teaching } \\
\text { certificate }\end{array}$ & \\
\hline \multicolumn{6}{|l|}{ West Darfur } \\
\hline Kondobe & 11.1 & 100.0 & 88.9 & 11.1 & 4.0 \\
\hline Kongo Haraza & 38.9 & 86.4 & 0 & 5.6 & 3.8 \\
\hline Habila & 69.5 & 85.2 & 13.7 & 24.2 & 6.5 \\
\hline Mornei & 58.4 & 0 & 0 & 19.7 & 8.8 \\
\hline Riyadh & 56.3 & 0 & 13.8 & 59.2 & 7.9 \\
\hline Forbaranga & 46.3 & 76.5 & 6.9 & 27.5 & 8.9 \\
\hline Arara & 46.9 & 0.0 & 0 & 81.3 & 5.1 \\
\hline Deleij & 48.4 & 100.0 & 7.3 & 67.7 & 11.6 \\
\hline Dorti & 11.1 & 100.0 & 0 & 22.2 & 7.3 \\
\hline Nertiti & 56.6 & 50.0 & 20.7 & 9.6 & 4.9 \\
\hline \multicolumn{6}{|l|}{ North Darfur } \\
\hline Kassab & - & - & - & - & - \\
\hline Birka Seira & 41.2 & 81.3 & 23.5 & 44.1 & 9.0 \\
\hline Fata Borno & 30.3 & 100.0 & 0 & 63.6 & 4.6 \\
\hline Zamzam & 69.2 & 1.6 & 1.5 & 64.6 & 9.9 \\
\hline Abbasi & 57.1 & 31.3 & 28.1 & 87.5 & 11.0 \\
\hline Al Salam & - & - & - & - & - \\
\hline El Seiraf & 27.3 & 63.6 & 45.4 & 9.1 & 2.9 \\
\hline Total & 54.8 & 39.5 & 8.3 & 46.7 & 8.7 \\
\hline Co-ed & 53.8 & 32.4 & 8.6 & 35.2 & 7.6 \\
\hline Girls only & 49.6 & 45.8 & 8.8 & 64.2 & 9.8 \\
\hline Boys only & 62.5 & 47.1 & 6.8 & 50.0 & 9.4 \\
\hline
\end{tabular}

NOTE: - indicates missing data. See endnote 19.

a training certificate and the mean years of teaching experience. Mean years of teaching experience varied from four to 11 years (with a mean of nine years), and the percentage with teaching certificates varied from 9 percent to 87 percent (with a mean of 47 percent). Female teachers were much more likely than male teachers to have a teaching certificate.

No more than 8 percent of teachers were reported to be volunteers, although in one community almost 90 percent were volunteers. At the time of the field work, the Government of Sudan was phasing out the system of volunteer teachers. By lowering standards required for a teaching certificate, the government has been able to hire many more certified primary school teachers.

Student-teacher ratios varied substantially and in some communities in North Darfur were extreme. Table 10 shows various indicators of teaching resources in relationship to needs. The student-teacher ratio is the most familiar indicator of class size and school quality. There is some consensus in the literature that class size matters for student learning. ${ }^{21}$ Using a guideline of 50 as a large but still feasible class size, four communities in West Darfur had excessive student-teacher ratios, ranging from 81:1 to 156:1. On average, student-teacher ratios were much higher (68:1) in co-ed schools than in single-sex schools (49:150:1). There was also a positive correlation across primary schools between the student-teacher ratio and the total number of enrolled students. Thus large schools tended to have more students per teacher. On the other hand, a negative correlation was found between the student-teacher ratio and the number of grades of instruction provided. Thus schools providing fewer grades of instruction seemed to be doubly disadvantaged in that they also had higher student-teacher ratios.

Teacher shortages were found in the majority of communities. The number of primary school teachers as a percent of the number required for universal primary school enrollment (Education 
TABLE 10 Primary school teachers available relative to educational needs

\begin{tabular}{|c|c|c|c|c|}
\hline \multirow[b]{2}{*}{$\begin{array}{l}\text { State/community/ } \\
\text { school type }\end{array}$} & \multirow[b]{2}{*}{$\begin{array}{l}\text { Number of } \\
\text { students } \\
\text { per teacher }\end{array}$} & \multirow[b]{2}{*}{$\begin{array}{l}\text { Number } \\
\text { of primary } \\
\text { teachers }^{\mathrm{a}}\end{array}$} & \multicolumn{2}{|c|}{$\begin{array}{c}\text { Number of } \\
\text { teachers required } \\
\text { for } E^{b} A^{\mathrm{b}} \text { based on }\end{array}$} \\
\hline & & & $\begin{array}{c}\text { OCHA } \\
\text { population } \\
\text { estimate }\end{array}$ & $\begin{array}{l}\text { Population size } \\
\text { reported in } \\
\text { community } \\
\text { survey }\end{array}$ \\
\hline \multicolumn{5}{|l|}{ West Darfur } \\
\hline Kondobe & 129 & 9 & 33 & 47 \\
\hline Kongo Haraza & 42 & 22 & 13 & 4 \\
\hline Habila & 46 & 82 & 115 & 94 \\
\hline Mornei & 107 & 138 & 244 & 400 \\
\hline Riyadh & 51 & 66 & 83 & 106 \\
\hline Forbaranga & 53 & 73 & 46 & 55 \\
\hline Arara & 58 & 39 & 23 & 49 \\
\hline Deleij & 156 & 31 & 88 & 104 \\
\hline Dorti & 81 & 18 & 38 & 48 \\
\hline Nertiti & 27 & 53 & 131 & 100 \\
\hline \multicolumn{5}{|l|}{ North Darfur } \\
\hline Kassab & - & - & - & - \\
\hline Birka Seira & 51 & 23 & 40 & 16 \\
\hline Fata Borno & 36 & 33 & 18 & 20 \\
\hline Zamzam & 42 & 130 & 236 & 240 \\
\hline Abbasi & 30 & 32 & 24 & 24 \\
\hline Al Salam & - & - & - & - \\
\hline El Seiraf & 45 & 12 & 14 & 24 \\
\hline Total & 58 & 2.5 & - & - \\
\hline Co-ed & 68 & 2.1 & - & - \\
\hline Girls only & 50 & 3.0 & - & - \\
\hline Boys only & 49 & 2.7 & - & - \\
\hline
\end{tabular}

for All (EFA)) gives a sense of educational resources in the community. Based on the fact that one person in five in the population is of primary school age, ${ }^{22}$ one primary school teacher would be required for every 250 persons if class size is assumed to be 50 and all primary-schoolage children attend school. By comparing the actual number of teachers with the number of teachers needed to permit all internally displaced children to attend all eight grades, one can see the extent to which each community falls short in terms of available teachers. Researchers developed two alternative estimates: one based on the 2007 OCHA population estimates and a second based on the population estimates reported to the interviewers (see Table 10).
For example, Nertiti in West Darfur has 53 primary school teachers but requires 131 primary school teachers according to OCHA population estimates to assure every internally displaced child a place in school with a class size no greater than 50 . There are 130 primary school teachers in Zamzam in North Darfur, but 236 primary school teachers would be required according to the same criteria. The actual size of the estimated teacher gap varies depending on whether one uses the OCHA population estimates or the population estimates derived from this survey. Regardless of population estimates, at least six communities in West Darfur and at least two in North Darfur fell short of full coverage by primary school teachers. 


\section{Conclusions}

The research undertaken shows a large variation in the conditions and basic educational services for children in IDP settlements in North and West Darfur. It identifies gaps in educational coverage and access for girls and boys, and highlights issues that affect the quality of education in terms of facilities and teachers. These results have policy implications for the Ministry of Education at the state and federal levels. A full list of recommendations is provided in the executive summary, including recommendations to expand the grade cover- age in primary schools not yet providing all eight grades of primary school, to provide non-formal educational services to the many primary-schoolage children who have not been able to attend or complete primary school, to ensure an adequate supply of qualified teachers in relation to the number of displaced children of school age, and to provide other essential services, including water, sanitation, and food, for each school. Because conditions vary from community to community, plans for provision and support should be tailored to the needs of individual communities.

\section{Notes}

1 Human Rights Watch, Q\&A: Crisis in Darfur. New York, April 25, 2008. www.hrw.org/english/docs/2004/05/05/darfur8536.htm

2 Aida F. Akl, "Darfur's tangled conflict wages on," Voice of America News, July 15, 2008. www.voanews.com/english/ NewsAnalysis/2008-07-22-voa28.cfm. See also Alex de Waal and Julie Flint, "In Darfur, from genocide to anarchy," Washington Post, August 28, 2007, p. Al3.

3 Human Rights Watch, Darfur 2007: Chaos by Design. New York, September 19, 2007.

4 National Public Radio (NPR), Expelled Aid Worker: Situation in Darfur is Dire, March 10, 2009. http://www.npr.org/ templates/story/story.php?storyId=101669767

5 Roxanne Escobles, "Darfur dead could number 300,000," April 23, 2008. www.guardian.co.uk/world/2008/ apr/23/sudan.unitednations?gusrc=rss\&feed=networkfront .

6 UNICEF, Women and Children in Darfur: February 2009. February 2009. http://www.unicef.org/sudan/arabic/UNICEF_ Darfur_fact_sheet_February_2009.pdf

7 USAID, The Humanitarian Situation in Darfur, 2008. www.usaid.gov/locations/sub-saharan_africa/sudan/

8 United Nations Office for the Coordination of Humanitarian Affairs (OCHA), Darfur HNP Profile No. 33, 2008.

9 United Nations, World Population Prospects: 2008 Revision. New York: United Nations, 2009.

10 INEE Working Group on Minimum Standards in partnership with the IASC Education Cluster, INEE Minimum Standards Reference Tool, 2007.

11 We were not able to sample IDPs living in the state capital as they are integrated with the rest of the population in ways that make it hard to sample them separately. We justified leaving them out because they were presumed to have the same access to schools as the host population, and educational services in the capital are better than in other settings.
12 OCHA, Darfur HNP Profile No. 33, 2008.

13 One of the six categories did not have any eligible communities.

14 As in West Darfur, one of the six categories did not have any eligible communities. While we had originally sampled ten communities in North Darfur from the 20 available, two were no longer in existence and one was too dangerous to visit.

15 All but one of our interviewers and team leaders were natives of Darfur; one team leader, while Darfurian, was born and lives in a large Darfurian settlement outside Khartoum.

16 Formal primary schools in the IDP communities are run by the Government of Sudan and follow the same design and curriculum as in the rest of the country. Primary school completion involves eight grades.

17 This study was completed prior to the eviction of large INGOs by the Government of Sudan following issuance of the warrant for the arrest of President Omar al-Bashir by the International Criminal Court in March 2009.

18 These figures simply indicate the length of the school day, from school opening to closing. They do not indicate actual teaching time, which may be less, given recess, school feeding, and other activities.

19 Teacher data are unavailable for seven of nine schools in Kassab and for one of 12 schools in Al Salam, so data are not presented for these two communities in Tables 9 and 10.

20 Cynthia B. Lloyd, New Lessons: The Power of Educating Adolescent Girls. New York: Population Council, 2009.

21 Cynthia B. Lloyd (ed.), Growing Up Global: The Changing Transition to Adulthood in Developing Countries. National Research Council/Institute of Medicine. Washington, DC: National Academy Press, 2005.

22 United Nations, World Population Prospects: 2008 Revision. New York: United Nations, 2009. 


\section{Annex 1. Map of affected populations in Darfur, including affected populations in the study sample}

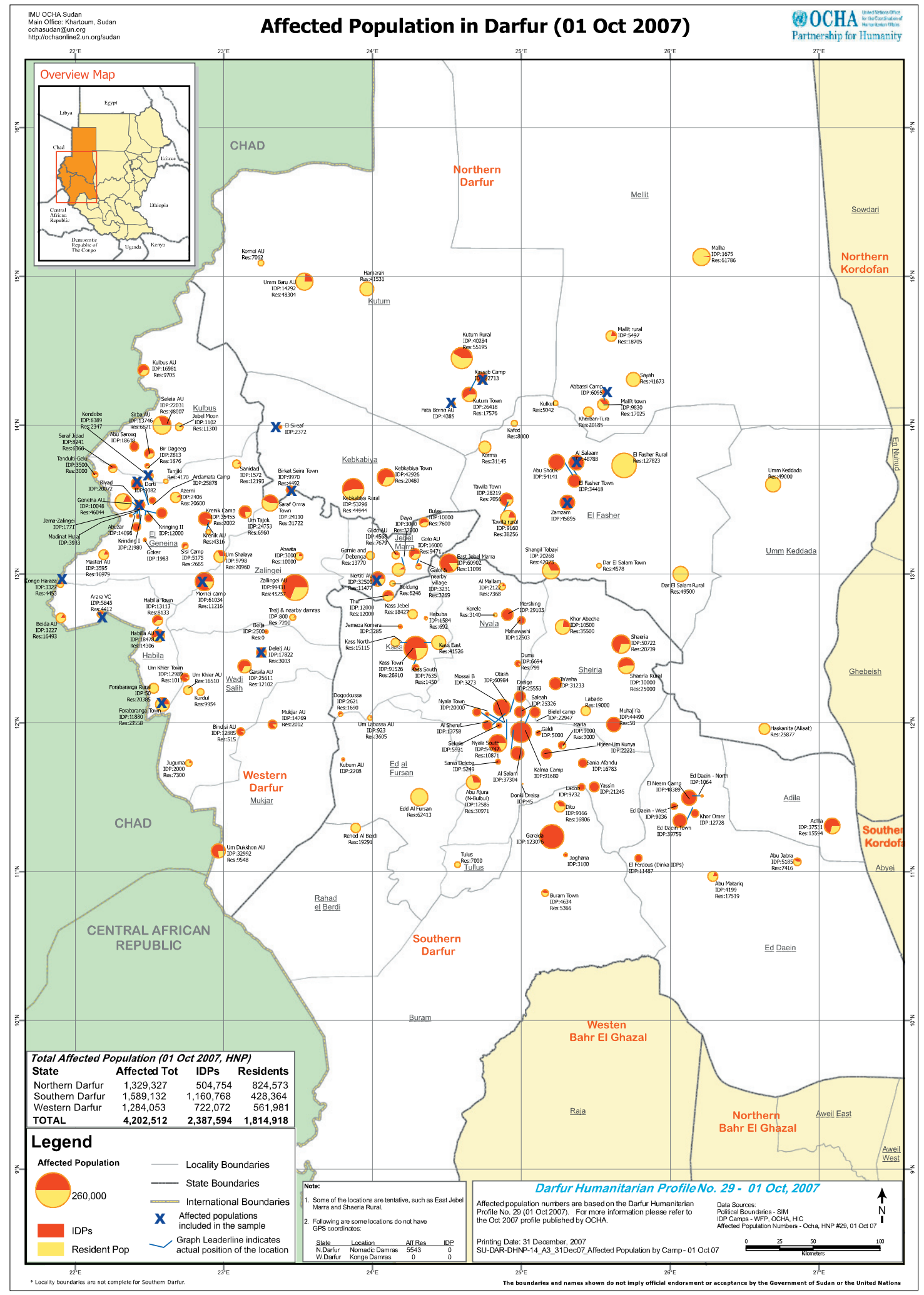




\section{Annex 2. Challenges of undertaking research in Darfur}

Much time was dedicated before the beginning of field visits to consultations with government officials in Khartoum and in the states of in El Fashir and El Geneina to explain the study and seek their collaboration and permission. In some cases, additional permission was required to enter settlements controlled by the Sudan Liberation Army (SLA), despite the fact that the SLA had signed a temporary peace accord with the government. In both states, logisticians were hired to facilitate arrangements and transportation in all of the communities selected for visits. Most settlements were only accessible by air using World Food Programme (WFP) flights, with transport costs nearly doubling during the time period of the research.

For security reasons, the researchers traveled like locals, using local transportation and inconspicuous identification so as not to call attention to themselves. After completing the community visits, however, the interviewers reported that this approach may not have been ideal. This is because the interviewers were sometimes mistaken for government officials, who had recently visited for the population census, or representatives of national NGOs affiliated with the Sudanese government's security apparatus. Particularly in North Darfur, where many of the settlements and communities were likely to have had a significant rebel presence, this may have led to some suspicion among the local population.*

The interviewers were concerned that the local sheikhs were often motivated to overestimate the size of the IDP community. For this reason, they tried to consult several other sources within each settlement to get more accurate assessment of the size of the displaced population. While the researchers had hoped that the population size reported by the sheikhs directly to them would be more accurate and up-to-date than the numbers reported by OCHA, they ultimately were left in some doubt. This is because the population numbers reported in the survey were often higher (in 12 out of 17 communities) and sometimes smaller (in four out of 17 communities) than population numbers reported for the same year by OCHA.

Accommodations were difficult in the communities distant from the state capital. Thanks to the generosity of WFP and Save the Children (USA), the interviewers were able to find accommodation in their guest houses in some of these remote locations.

Communications between the research communities and the state capitals as well as the nearest Population Council office in Khartoum were also difficult due to lack of internet and cell phone service. Visits to two camps in West Darfur near the border with Chad had to be delayed for about six months until the end of the study period because of rebel invasions. Researchers were unable to visit two settlements (Tawilla and Umm Baru) because of security concerns.

Despite these challenges, the fieldwork proceeded relatively smoothly. This was undoubtedly the result of the thorough groundwork of the logisticians and the careful work done by the local study director and the researchers to build rapport with local officials and NGOs within each of the communities they visited.

The international advisory committee recommended that the researchers take special precautions to keep the data secure and to transmit them as quickly as possible once the interviewers had left the community.

*One community was determined to be too dangerous to visit because of ongoing ethnic tensions. In several locations, interviewers heard gunshots at night. In one settlement, a female interviewer could not participate in the data collection; local residents were suspicious because she came from a recognizably different ethnic group. 


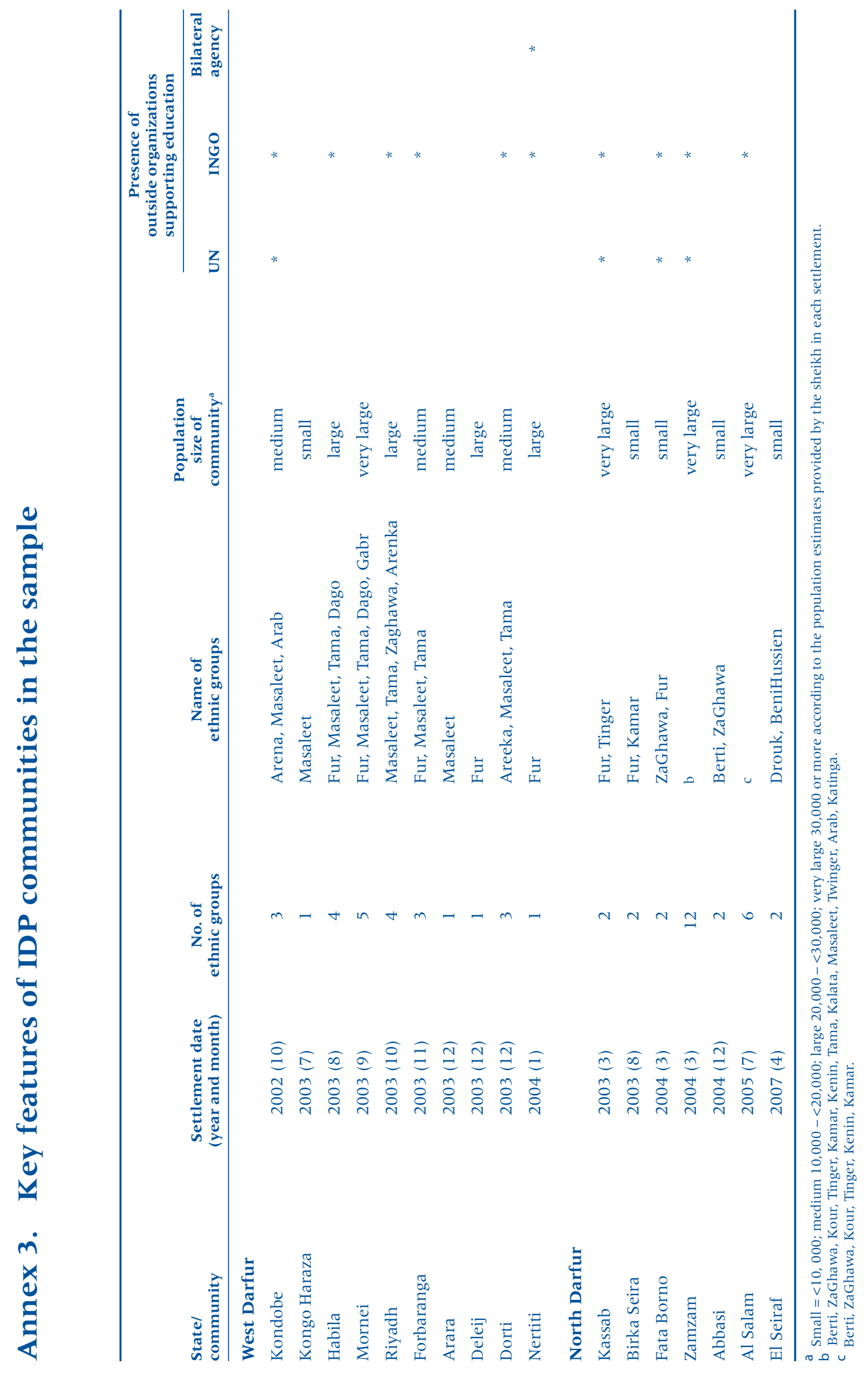

